\title{
Effects on fish community induced by installation of two gas platforms in the Adriatic Sea
}

\author{
Gianna Fabi $^{1, *}$, Fabio Grati $^{1}$, Micaela Puletti ${ }^{2}$, Giuseppe Scarcella ${ }^{1}$ \\ ${ }^{1}$ Istituto di Scienze Marine, Sezione Pesca Marittima, CNR, Largo Fiera della Pesca, 60125 Ancona, Italy \\ ${ }^{2}$ ENI S.p.A., Divisione Exploration \& Production, Unità Geografica Italia, Via del Marchesato 13, 48023 Marina di Ravenna, Italy
}

\begin{abstract}
The Regina $\left(R_{p}\right)$ and Annalisa $\left(A_{p}\right)$ gas platforms, placed in the northern Adriatic Sea at different depths and distances from the coast, were monitored for 3 yr to evaluate changes induced by their construction on natural-habitat fish assemblages. Fishes were sampled monthly with a trammel net both at the rigs and at 2 open-sea control sites. From a qualitative point of view, both platforms showed their influence within the first year after their installation, inducing higher species richness and greater diversity of fish assemblages due to the appearance and constant occurrence of reef-dwelling or partially reef-dwelling species, which are rare in the natural habitat. In terms of biomass, the platform further offshore and in deeper water $\left(A_{p}\right)$ had higher fish abundances than that closer to shore in shallower waters, revealing a greater and faster aggregation effect. This difference was mainly due to an increase in pelagic and nekto-benthic fishes, which are partially attracted by hard substrates. A few voracious predators were also recorded at this site, probably in response to the increase in prey biomass.
\end{abstract}

KEY WORDS: Gas platforms $\cdot$ Fish community $\cdot$ Adriatic Sea

Resale or republication not permitted without written consent of the publisher

\section{INTRODUCTION}

The role of gas and oil platforms in the distribution and abundance of local fish communities has been investigated in a few areas such as southern California, Gulf of Mexico, western coast of Africa and North Sea. In these areas there is evidence that offshore platforms support fish and invertebrate populations and, hence, act as artificial reefs inducing a redistribution of the resources and providing, in some cases, acceptable conditions for increase of biomass (Hastings et al. 1976, Olsen \& Valdemarsen 1977, Valdermarsen 1979, Gallaway et al. 1981, Putt 1982, Gerlotto et al. 1989, Stanley \& Wilson 1990, 1991, 1996, 1997, 1998, ScarboroughBull \& Kendall 1994, Furevik \& Valdemarsen 1995, Love et al. 1999, 2000, Page et al. 1999, Jørgensen et al. 2002, Løkkeborg et al. 2002). As these structures extend throughout the entire water column, their effects are not confined to demersal fishes, but also involve pelagic species that congregate about them, attracted either by the solid, reef-like nature of the supporting structures, or by the numerous smaller forage organisms in the area. Small pelagic fishes tend to remain from near the surface to mid-depth within or up-current from the platforms, while large, predatory, pelagic species are reported to swim from the surface to mid-depth around the platforms, rarely venturing within them (Hastings et al. 1976, Gallaway et al. 1981, Stanley \& Wilson 1990, Scarborough-Bull \& Kendall 1994).

In the Mediterranean Sea, little information exists on fish resources associated with these installations, and only in the last few years have specific investigations been undertaken in the northern and central Adriatic Sea, where about 90 platforms are located (Bombace et al. 1999, Fabi et al. 2002a, in press). The aim was to evaluate the changes induced by the installation of these structures on natural-habitat fish assemblages of this semi-enclosed basin, which is characterised by a flat and homogeneous seabed consisting of a wide continental shelf that is completely trawlable, where the offshore platforms provide the only hard-bottom habitat, and by peculiar oceanographic features that 
strongly depend on its geographical location and morphology, climatic conditions, freshwater river inflow and water exchange with the Ionian Sea.

The present paper reports the results of 3 yr monitoring programme carried out in cooperation with ENI S.p.A. (Ente Nazionale Idrocarburi) on 2 gas platforms in the northern Adriatic Sea, with different depths, water circulation conditions and bottom types.

\section{MATERIALS AND METHODS}

Study sites. The study was carried out in the vicinity of Regina $\left(\mathrm{R}_{\mathrm{p})}\right.$ and Annalisa $\left(\mathrm{A}_{\mathrm{p})}\right.$, two 4-leg gas platforms located 16 and $35 \mathrm{~km}$ offshore, respectively (Fig. 1), on a flat seabed without seaweed and seagrass meadows and far from natural and/or artificial hard substrates.

The $R_{p}$ jacket (submerged part of the platform) was installed in March 1997 on a sand-mud bottom at 21-22 m depth, about $12 \mathrm{~km}$ from an 8-leg platform; the drilling operations finished in October of the same year. The $A_{p}$ platform was set up in February 1999 on a relict sand seabed at 53-54 m depth, about $5.5 \mathrm{~km}$ from an 8-leg platform. Drilling operations started in June and were completed in December of the same year, with an interruption during the summer months due to technical problems.

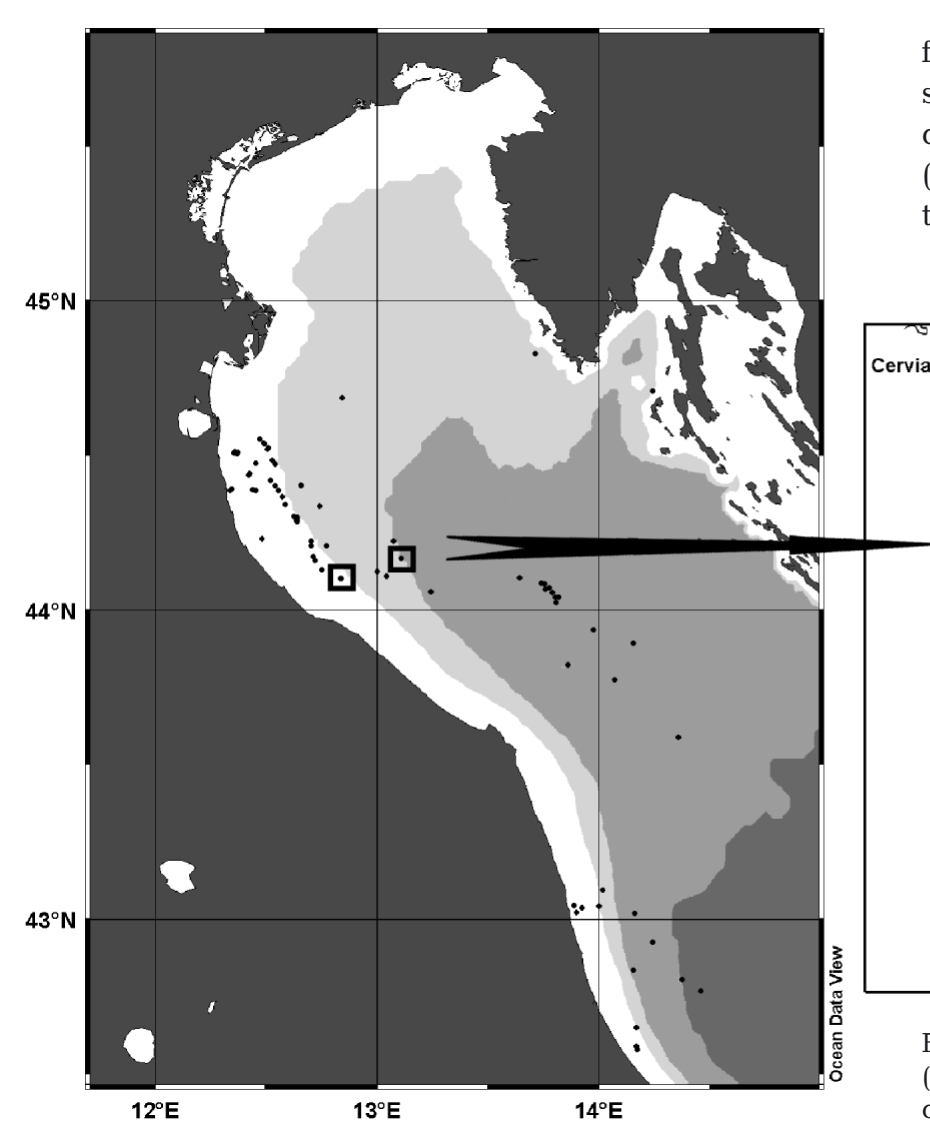

The 2 platforms are about $22 \mathrm{~km}$ apart and, in terms of overall dimensions, the total volume enclosed by the $A_{p}$ rig $\left(14200 \mathrm{~m}^{3}\right)$ is $33 \%$ greater than that of the $R_{p}$ rig $\left(9500 \mathrm{~m}^{3}\right)$.

Data collection. Fish collections were made within a $50 \mathrm{~m}$ radius of the 2 platforms and also at 2 open-sea control sites about $6.5 \mathrm{~km}$ from $\mathrm{R}_{\mathrm{p}}\left(\mathrm{R}_{\mathrm{c}}\right)$ and $3.7 \mathrm{~km}$ from $A_{p}\left(A_{c}\right)$, respectively, on the same type of seabed and at similar depth. Sampling was carried out with a bottom trammel net $(500 \mathrm{~m}$ long, $3 \mathrm{~m}$ high, inner mesh size $72 \mathrm{~mm}$, outer mesh size $400 \mathrm{~mm}$ ), which was lowered into the water at dusk and hauled in at dawn (an average deployment time of $12 \mathrm{~h}$ ). The platforms and their respective control sites were sampled simultaneously in order to operate in the same weather conditions.

From February 1998 to December 20001 sampling per month was made at both $\mathrm{R}_{\mathrm{p}}$ and $\mathrm{R}_{\mathrm{c}}$ (a total of 35 samples per site), while 30 monthly trips were made from March 1999 to December 2001 at both $\mathrm{A}_{\mathrm{p}}$ and $\mathrm{A}_{\mathrm{c}}$ (Table 1).

All fishes in the catches were identified to the lowest taxonomic level. Total length was measured to the lower $0.5 \mathrm{~cm}$, and weight to the lower $1 \mathrm{~g}$ for each individual, except for sardines Sardina pilchardus and anchovies Engraulis encrasicolus, which were counted and then weighed together. Cephalopods (mantle length) and crustaceans of commercial interest (carapace length) were measured and weighed in the same way.

Data analysis. Pelagic, nekto-benthic and benthic fishes, as well as molluscs and crustaceans were treated separately. Moreover, species within each group were categorised as either attracted (AT), partially-attracted (PA) or non-attracted (NA) on the basis of their behaviour towards hard substrates. AT species are habitat-limited, 
obligatory reef-dependent species that use natural or artificial substrates for shelter and probably forage on them or in their immediate vicinity. PA species are mobile, partially reef-dependent species that may be temporarily attracted to hard substrates, but may be also observed in open-sea areas away from rocky habitats. NA species are those that occur naturally on soft bottoms but may be present after reef deployment, even though they have no relationship with hard substrates (Bombace et al. 1994).

Because of differences in the net deployment times (longer in winter than in summer), and because the net was sometimes damaged, indices of abundance (number of individuals) and biomass were standardized for a $12 \mathrm{~h}$ set period and $500 \mathrm{~m}$ of net.

Total species richness (S) was computed for each site as total number of species caught in the overall sampling period and in each year. Mean abundance $(\mathrm{N})$, biomass (W), number of species $\left(\mathrm{S}_{\mathrm{m}}\right)$ and the ShannonWiener diversity index $\left(H^{\prime}\right.$, log-base 10 ; Pielou 1974) per year were also calculated for each site.

For $\mathrm{N}, \mathrm{W}, \mathrm{S}_{\mathrm{m}}$ and $H^{\prime}$, a statistical comparison between each platform and the respective control site was made using an unbalanced, fixed effect, 2-way ANOVA (Lindman 1992), where the factors were site and year, the latter being considered as year of construction ( $\mathrm{YC}$, only for $\mathrm{A}_{\mathrm{p}}$ and $\mathrm{A}_{\mathrm{c}}$ ), first year after construction (YA1), second year after construction (YA2) and third year after construction (YA3, only for $\mathrm{R}_{\mathrm{p}}$ and $\mathrm{R}_{\mathrm{ci}}$ Table 1). Prior to statistical analysis, normal distribution and heterogeneity of variances were evaluated by Kolmogorov-Smirnov and Bartlett tests, respectively (Lindman 1992). When the latter test was significant, the relationship between the means and the respective SD was analysed to check whether the ANOVA assumptions were effective. Based on these tests, N and $\mathrm{W}$ data were log-transformed. The Tukey HSDtest corrected for unbalanced samples was used to make comparisons across all pairs of group means when corresponding ANOVA tests were highly significant $(\mathrm{p}<0.01)$ or significant $(\mathrm{p}<0.05)$.

Table 1. Timetable of monitoring at the 2 platforms and their respective control sites. YC: year of construction of platform; YA1: 1st year after construction; YA2: 2nd year after construction; YA3: 3rd year after construction. $\mathrm{R}_{\mathrm{p}}=$ Regina platform; $\mathrm{R}_{\mathrm{C}}=$ Regina control site; $\mathrm{A}_{\mathrm{p}}=$ Annalisa platform; $\mathrm{A}_{\mathrm{c}}=$ Annalisa control site

\begin{tabular}{|c|c|c|c|c|c|}
\hline & 1997 & 1998 & 1999 & 2000 & 2001 \\
\hline \multirow{4}{*}{$\begin{array}{l}\mathrm{R}_{\mathrm{p}} \\
\mathrm{R}_{\mathrm{c}} \\
\mathrm{A}_{\mathrm{p}} \\
\mathrm{A}_{\mathrm{c}}\end{array}$} & $\mathrm{YC}$ & YA1 & YA2 & YA3 & \\
\hline & $\mathrm{YC}$ & YA1 & YA2 & YA3 & \\
\hline & & & $\mathrm{YC}$ & YA1 & YA2 \\
\hline & & & $\mathrm{YC}$ & YA1 & YA2 \\
\hline$\square$ & urvey & & vey & & rey yea \\
\hline
\end{tabular}

Kruskal-Wallis test was applied to evaluate differences in abundance and weight of the main species categories, because data strongly deviated from normal distribution and homogeneity of variances.

Size-frequency distributions of catches of the most representative demersal species (Trisopterus minutus capelanus) recorded at the 2 platforms were computed. A comparison of demographic structure of total catches of this species between each platform and the respective control site as well as between $R_{p}$ and $A_{p}$ was made by a non-parametric Kolmogorov-Smirnov test (Siegel 1956).

\section{RESULTS}

\section{Species richness}

A total of 55 species ( 47 fishes, 4 molluscs and 4 crustaceans) were recorded at $\mathrm{R}_{\mathrm{p}}$ and 46 (42 fishes, 2 molluscs and 2 crustaceans) at $\mathrm{R}_{\mathrm{c}}$ (Appendix 1), while 61 species (51 fishes, 5 molluscs and 5 crustaceans) were caught at $A_{p}$ and 52 (43 fishes, 6 molluscs and 3 crustaceans) at $\mathrm{A}_{\mathrm{c}}$ (Appendix 2).

Also, total annual species richness (S) was always higher at the platforms (Fig. 2), as was number of species $\left(\mathrm{S}_{\mathrm{m}}\right)$ per catch between $\mathrm{R}_{\mathrm{p}}$ and $\mathrm{R}_{\mathrm{c}}$ (Fig. 2, Table 2), where it remained practically constant during the overall sampling period. In contrast, $\mathrm{S}_{\mathrm{m}}$ showed similar values at $A_{p}$ and $A_{c}$ in $Y C$, while in the 2 following years it gradually increased at the former site and remained constant at the latter. Statistical analysis confirmed that the value reached at $A_{p}$ in YA2 was significantly higher than that at the same site in $\mathrm{YC}$ and than those at $A_{C}$ in each sampling year (Table 2).

\section{Catch rates and composition}

$\mathrm{N}$ gradually increased at $\mathrm{R}_{\mathrm{p}}$ during the 3 yr after construction, while a decrease occurred at $\mathrm{R}_{\mathrm{c}}$ (Fig. 3, Appendix 1). In terms of biomass, catch rates were always higher at the platform and a slight increment

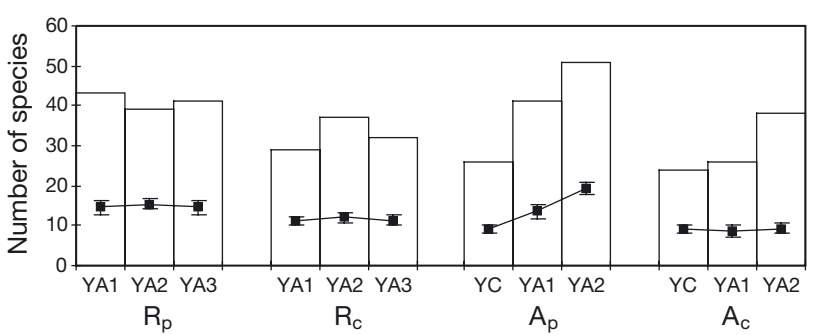

Fig. 2. Total (columns) and mean \pm SE (data points) species richness per year in catches at the 2 platforms and their respective control sites. Abbreviations as in Table 1 
Table 2. Results of 2-way ANOVA applied to mean species richness $\left(\mathrm{S}_{\mathrm{m}}\right)$ and species diversity index $\left(H^{\prime}\right)$ at 2 gas platforms and their respective control sites. ${ }^{* *}, \gg=$ highly significant; $>=$ significant; $b, w$ : between group/within group; other abbreviations as in Table 1

\begin{tabular}{|c|c|c|c|c|c|c|c|c|}
\hline \multirow{2}{*}{ Factor } & \multirow{2}{*}{$\begin{array}{c}\mathrm{df} \\
(\mathrm{b}, \mathrm{w})\end{array}$} & \multicolumn{4}{|c|}{ Species richness $\left(\mathrm{S}_{\mathrm{m}}\right)$} & \multicolumn{3}{|c|}{ Species diversity $\left(H^{\prime}\right)-$} \\
\hline & & MS & F & $\mathrm{p}$ & Tukey's HSD & MS & $F$ & $\mathrm{p}$ \\
\hline \multicolumn{9}{|c|}{ Regina platform } \\
\hline Site & $(1,64)$ & 205.455 & 7.173 & $0.008^{* *}$ & $R_{p} \gg R_{c}$ & 0.278 & 9.425 & $0.003^{* *}$ \\
\hline Year & $(2,64)$ & 5.521 & 0.193 & 0.825 & & 0.090 & 3.076 & 0.053 \\
\hline Site $\times$ Year & $(2,64)$ & 0.378 & 0.013 & 0.986 & & 0.012 & 0.418 & 0.660 \\
\hline \multicolumn{9}{|c|}{ Annalisa platform } \\
\hline Site & $(1,54)$ & 392.365 & 18.639 & $0.000^{* *}$ & & 0.079 & 1.916 & 0.172 \\
\hline Year & $(2,54)$ & 140.177 & 6.659 & $0.003^{* *}$ & & 0.126 & 3.065 & 0.055 \\
\hline Site $\times$ Year & $(2,54)$ & 126.207 & 6.000 & $0.004^{* *}$ & $\begin{array}{c}A_{p} Y A 2 \gg A_{c} \\
A_{p} \text { YA2 } \gg A_{p} Y C\end{array}$ & 0.034 & 0.821 & 0.445 \\
\hline
\end{tabular}

was observed at both sites in YA3. No statistical differences were found for $\mathrm{N}$ or $\mathrm{W}$ between sites and sampling years (Table 3).

In contrast, there were always higher annual mean catch rates, both as number of individuals and biomass, at $A_{p}$ than at $A_{c}$ (Fig. 3). A gradual increase occurred at the platform during the overall sampling period until, in YA2, a significantly higher value was recorded than in $\mathrm{YC}$ at the same site and in each year at $A_{C}$ (Table 3).

Fishes made up more than $75 \%$ of the overall catch in weight at $R_{p}$ and $R_{c}$ and more than $90 \%$ at $A_{p}$ and its respective control site (Fig. 3). Pelagic species dominated at the first 3 sites, followed by nekto-benthic fishes at the platforms and benthic fishes at $R_{c}$. The
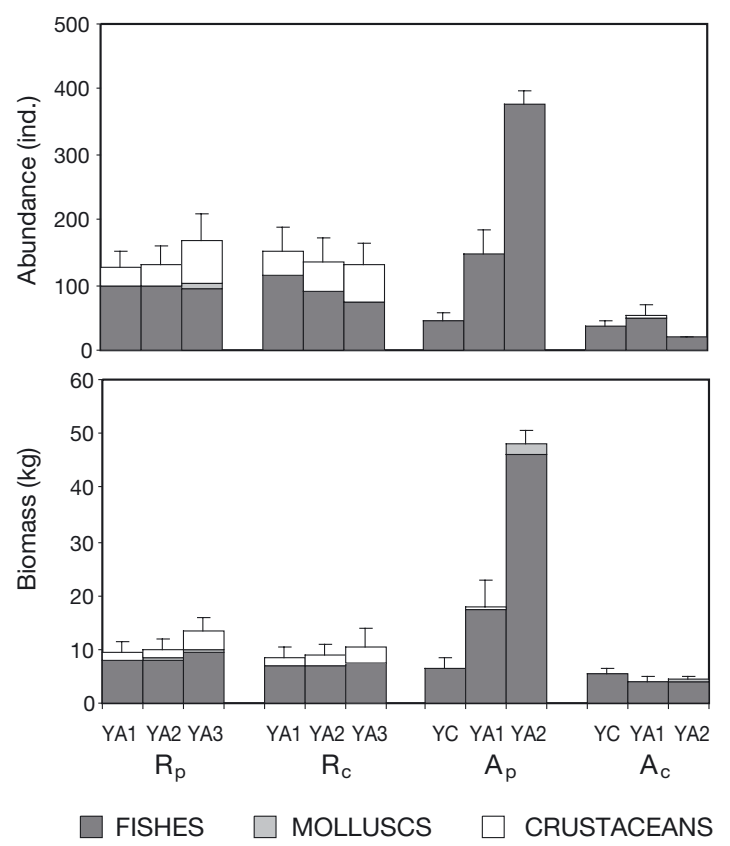

Fig. 3. Mean $(+\mathrm{SE})$ catch abundance and biomass of fishes, molluscs and crustaceans per set of $500 \mathrm{~m}$ and $12 \mathrm{~h}$ at the 2 platforms and their respective control sites in each survey year. Abbreviations as in Figs. 1 \& 2 last group was the most important in catches at $A_{C^{\prime}}$ followed by pelagic species.

Pelagic fishes were mainly gregarious PA (Boops boops, Spicara flexuosa, Scomber spp., Trachurus spp.) and NA (Alosa fallax, Engraulis encrasicolus, Sardina pilchardus) species (Fig. 4, Appendices 1 \& 2). The former group dominated at the platforms and significantly increased over the years at $A_{p}$. In contrast, the 2 categories gave similar catch yields at the control sites. Comparison between each platform and its respective control site indicated that the catch rates of PA fishes were generally higher around the structures, even though the difference was statistically significant only between $A_{p}$ and $A_{c}$ (Table 4). In contrast, greater catch rates (as biomass) of NA species were recorded at $R_{c}$ compared to $R_{p}$, while no differences were recorded between $A_{p}$ and $A_{c}$ (Table 4).

The only AT pelagic fish recorded in the whole sampling period was Seriola dumerili, a voracious predator mainly caught near the platforms (Appendices $1 \& 2$ ).

Nekto-benthic species were mostly AT (Diplodus sargus, Umbrina cirrosa, Sciaena umbra) and PA (Diplodus annularis, Pagellus bogaraveo, Trisopterus minutus capelanus) at $\mathrm{R}_{\mathrm{p}}$, PA (P. bogaraveo, T. minutus capelanus) and NA (Merluccius merluccius, Merlangius merlangus) at $\mathrm{A}_{\mathrm{p}}$ and NA at both control sites (Fig. 4, Appendices 1 \& 2).

Comparison between each platform and its control site showed that AT and PA species were significantly more abundant at $R_{p}$ than at $R_{c}$ (Table 4), while between $A_{p}$ and $A_{c}$ the difference was significant only for PA fishes. Over the 3 sampling years, this last category significantly increased at $A_{p}$ and decreased at $R_{p}$, where it was gradually replaced by AT species. These trends were mainly due to variations of the poor cod Trisopterus minutus capelanus, which represented the most important nekto-benthic fish at both platforms (Appendices 1 \& 2). Comparison of poor cod catch demography between each platform and the respective control site showed a highly significant difference 
Table 3. Results of 2 -way ANOVA applied to $\log _{10}$-transformed data of abundance (N) and biomass (W) recorded at the 2 platforms and their respective control sites. ${ }^{* *}, \gg=$ highly significant; $>$ = significant. Other abbreviations as in Tables $1 \& 2$

\begin{tabular}{|c|c|c|c|c|c|c|c|c|}
\hline \multirow[t]{2}{*}{ Factor } & \multirow{2}{*}{$\begin{array}{c}\mathrm{df} \\
(\mathrm{b}, \mathrm{w})\end{array}$} & \multicolumn{3}{|c|}{-Abundance $(\mathrm{N})$} & \multicolumn{4}{|c|}{ Biomass $(\mathrm{W})$} \\
\hline & & MS & $F$ & $\mathrm{p} \quad$ Tukey's HSD & MS & $F$ & $\mathrm{p}$ & Tukey's HSD \\
\hline \multicolumn{9}{|c|}{ Regina platform } \\
\hline Site & $(1,64)$ & 0.002 & 0.009 & 0.922 & 0.303 & 1.770 & 0.189 & \\
\hline Year & $(2,64)$ & 0.001 & 0.006 & 0.994 & 0.063 & 0.370 & 0.692 & \\
\hline Site $\times$ Year & $(2,64)$ & 0.019 & 0.123 & 0.884 & 0.001 & 0.006 & 0.994 & \\
\hline \multicolumn{9}{|c|}{ Annalisa platform } \\
\hline Site & $(1,54)$ & 4.749 & 23.518 & $0.000^{* *}$ & 3.313 & 19.130 & $0.000^{* *}$ & \\
\hline Year & $(2,54)$ & 0.303 & 1.501 & 0.232 & 0.437 & 2.524 & 0.090 & \\
\hline Site $\times$ Year & $(2,54)$ & 1.488 & 7.371 & $\begin{aligned} 0.002^{* *} & \mathrm{~A}_{\mathrm{p}} \mathrm{YA} 2 \\
\mathrm{~A}_{\mathrm{p}} \mathrm{YA} 1 & \gg \mathrm{A}_{\mathrm{c}} \mathrm{YA2} \\
\mathrm{A}_{\mathrm{p}} \mathrm{YA} 2 & \gg \mathrm{A}_{\mathrm{p}} \mathrm{YC}\end{aligned}$ & 1.373 & 7.927 & $0.001^{* *}$ & $\begin{array}{c}A_{p} Y A 2>A_{c} \\
A_{p} Y A 1>A_{c} Y A 2 \\
A_{p} Y A 2 \gg A_{p} Y C\end{array}$ \\
\hline
\end{tabular}

only between $\mathrm{R}_{\mathrm{p}}$ and $\mathrm{R}_{\mathrm{c}}$ (Fig. 5, Table 5), with a higher mean size at the platform. Also the catches at $\mathrm{R}_{\mathrm{p}}$ and $A_{p}$ in the same years (1999 and 2000) were statistically different (Table 5) mainly in a greater occurrence of large specimens at the former platform (Fig. 5).

NA species were more abundant at the control sites than at the respective platforms, although the difference was significant only between $R_{p}$ and $R_{c}$ (Fig. 4, Table 4). A noticeable increase in weight of this category was recorded in YA1 at $\mathrm{A}_{\mathrm{p}}$, due to an exceptional catch of Myliobatis aquila, but it was not statistically significant. Conversely a gradual, significant decrease occurred at $\mathrm{A}_{\mathrm{C}}$ (Fig. 4, Table 4).

Benthic fishes were mostly NA species at each site (Fig. 4) and were mainly represented by Trigla lucerna, Solea vulgaris and Squalus acanthias, the latter species being recorded only at $A_{p}$ and $A_{c}$ (Appendices $1 \& 2$ ). Catches of this category were generally higher at control sites, although a significant difference was observed only between $R_{p}$ and $R_{c}$ in terms of biomass (Table 4). Rockfishes such as scorpenids (especially Scorpaena porcus and S. notata) and Mullus surmuletus made up most of the AT benthic fish catches, which were significantly greater at the platforms (Table 4). Comparison among years revealed a highly significant increase of this category from $\mathrm{YC}$ to YA2 at $A_{p}$ and $A_{c}$ (Fig. 4, Table 4).

Finally, the PA benthic fishes were very scarce in catches, being represented only by small quantities of Gobius niger at each site (Appendices $1 \& 2$ ).

Molluscs were also very scarce, making up less than $4 \%$ of the overall catches at each site (Fig. 3, Appen-

Table 4. Kruskal-Wallis test (p-values) for main species groups at 2 gas platforms. AT: attracted; PA: partially attracted; NA: non-attracted; ${ }^{* *}$ highly significant; ${ }^{*}$ significant; $\mathrm{n}=$ number of observations; other abbreviations as in Table 1

\begin{tabular}{|c|c|c|c|c|c|c|c|c|c|c|}
\hline \multirow[t]{2}{*}{ Factor } & \multirow[t]{2}{*}{ df, n } & \multirow{2}{*}{$\begin{array}{c}\text { Crusta- } \\
\text { ceans }\end{array}$} & \multirow[t]{2}{*}{ Molluscs } & \multicolumn{2}{|c|}{ Benthic fishes } & \multicolumn{3}{|c|}{ Nekto-benthic fishes } & \multicolumn{2}{|c|}{ Pelagic fishes } \\
\hline & & & & $\mathrm{AT}$ & NA & $\mathrm{AT}$ & PA & NA & PA & NA \\
\hline \multicolumn{11}{|c|}{ Regina platform } \\
\hline \multicolumn{11}{|c|}{ No. of individuals } \\
\hline Site & 1,70 & 0.668 & 0.111 & $0.000^{* *}$ & 0.073 & $0.001^{* *}$ & $0.000^{* *}$ & $0.027^{*}$ & 0.061 & 0.078 \\
\hline Year (Rp) & 2,35 & 0.221 & 0.216 & 0.831 & 0.655 & 0.088 & $0.020^{*}$ & 0.266 & 0.747 & 0.822 \\
\hline Year (Rc) & 2,35 & 0.221 & 0.130 & 0.287 & 0.494 & 0.196 & 0.312 & 0.147 & 0.821 & 0.377 \\
\hline \multicolumn{11}{|l|}{ Weight } \\
\hline Site & 1,60 & 0.898 & 0.223 & $0.000^{* *}$ & 0.322 & 0.115 & $0.000^{* *}$ & 0.811 & $0.000^{* *}$ & 0.934 \\
\hline Year (Ap) & 2,30 & 0.530 & $0.032^{*}$ & $0.001^{* *}$ & 0.888 & 0.615 & $0.047^{*}$ & 0.572 & $0.002^{* *}$ & 0.942 \\
\hline Year (Ac) & 2,30 & 0.761 & 0.187 & $0.007^{* *}$ & 0.310 & 0.560 & 0.618 & $0.019^{*}$ & 0.732 & 0.109 \\
\hline \multicolumn{11}{|c|}{ Annalisa platform } \\
\hline \multicolumn{11}{|c|}{ No. of individuals } \\
\hline Site & 1,60 & 0.732 & 0.230 & $0.000^{* *}$ & 0.871 & 0.107 & $0.000^{* *}$ & 0.904 & $0.000^{* *}$ & 0.377 \\
\hline Year (Ap) & 2,30 & 0.843 & $0.033^{*}$ & $0.001^{* *}$ & 0.706 & 0.561 & $0.047^{*}$ & 0.433 & $0.001^{* *}$ & 0.967 \\
\hline Year (Ac) & 2,30 & 0.793 & 0.208 & $0.007^{* *}$ & 0.351 & 0.560 & 0.700 & $0.013^{*}$ & 0.930 & 0.300 \\
\hline \multicolumn{11}{|l|}{ Weight } \\
\hline Site & 1,60 & 0.898 & 0.223 & $0.000^{* *}$ & 0.322 & 0.115 & $0.000^{* *}$ & 0.811 & $0.000^{* *}$ & 0.934 \\
\hline Year (Ap) & 2,30 & 0.530 & $0.032^{*}$ & $0.001^{* *}$ & 0.888 & 0.615 & $0.047^{*}$ & 0.572 & $0.002^{* *}$ & 0.942 \\
\hline Year (Ac) & 2,30 & 0.761 & 0.187 & $0.007^{* *}$ & 0.310 & 0.560 & 0.618 & $0.019^{*}$ & 0.732 & 0.109 \\
\hline
\end{tabular}



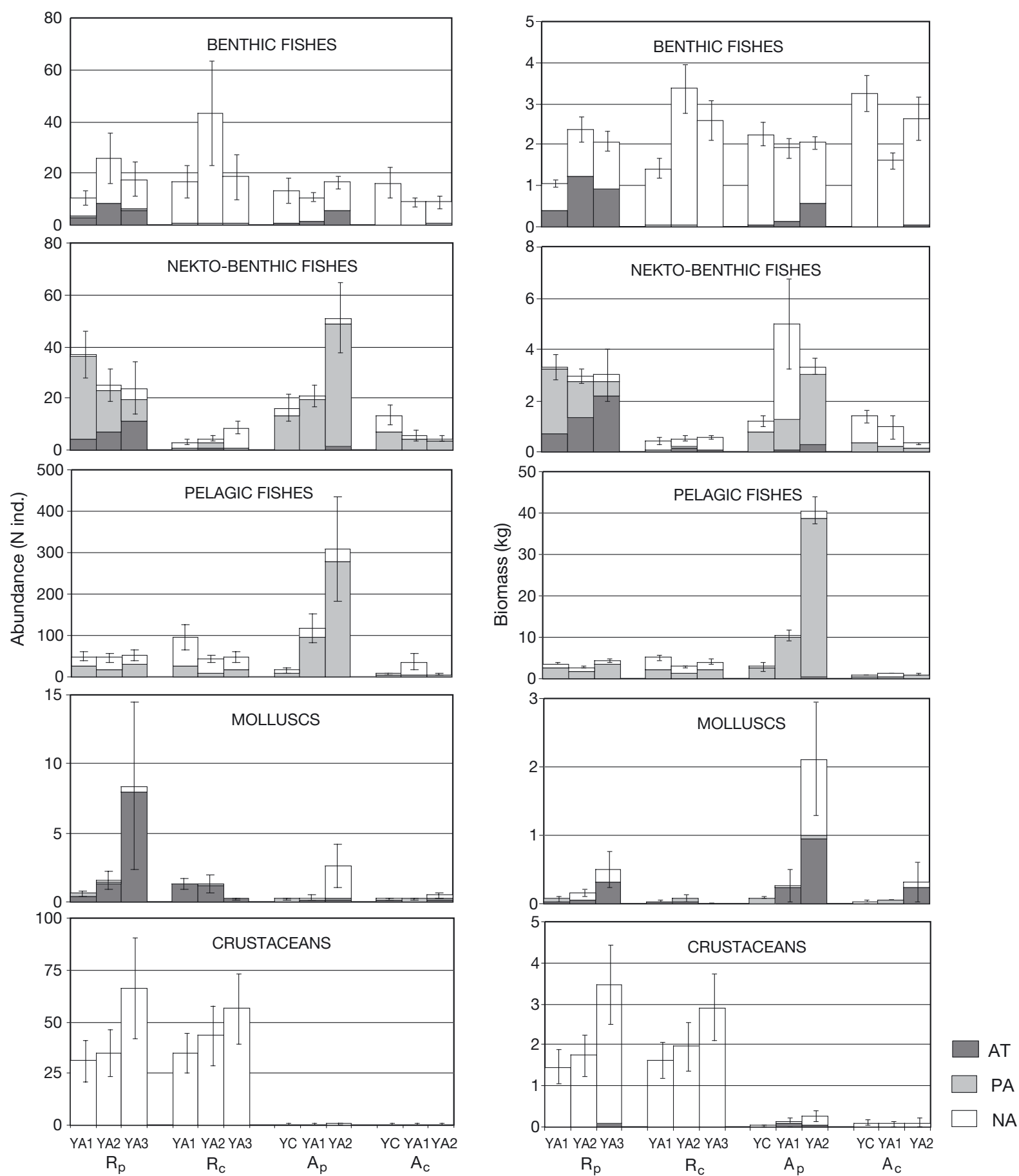

Fig. 4. Mean $( \pm$ SE) catch abundance and biomass per set of $500 \mathrm{~m}$ and $12 \mathrm{~h}$ of different species groups at the 2 platforms and their respective control sites in each survey year. AT: attracted; PA: partially attracted; NA: non-attracted; other abbreviations as in Figs. 1 \& 2

dices 1 \& 2). In terms of biomass, catches were dominated by Bolinus brandaris (AT) at $\mathrm{R}_{\mathrm{p}}$ and $\mathrm{R}_{\mathrm{c}}$ and were significantly higher at the platform (Fig. 4, Table 4). Conversely, similar yields were recorded at $\mathrm{A}_{\mathrm{p}}$ and $\mathrm{A}_{\mathrm{c} i}$ at these sites, the most representative species were Sepia officinalis (NA) and Octopus vulgaris (AT), which significantly increased at $\mathrm{A}_{\mathrm{p}}$ in YA2.
Crustaceans made up 20 and $24 \%$ of the total catches at $R_{p}$ and $R_{c}$ respectively, while they were less important at $\mathrm{A}_{\mathrm{p}}(0.5 \%)$ and $\mathrm{A}_{\mathrm{c}}(2 \%)$. They were mainly NA species such as Squilla mantis and Penaeus kerathurus at the 2 former sites, and Maja squinado and Nephrops norvegicus at $\mathrm{A}_{\mathrm{p}}$ and $\mathrm{A}_{\mathrm{c}}$ (Fig. 4, Appendices 1 \& 2). AT species were exclusively caught around the platforms 


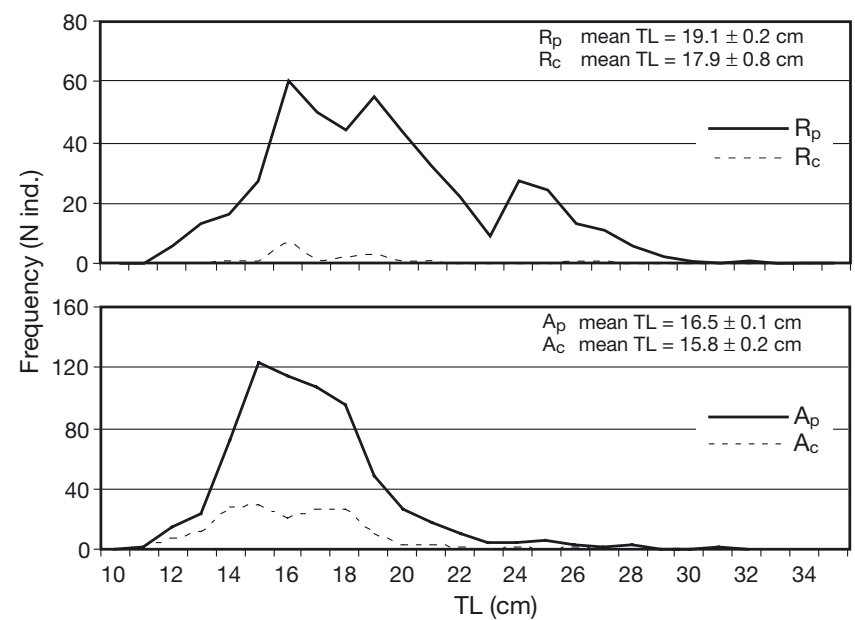

Fig. 5. Trisopterus minutus capelanus. Size-frequency distributions in catches at the 2 platforms and their respective control sites in overall sampling period. TL: total length; other abbreviations as in Fig. 1

and consisted of Maja crispata at $\mathrm{R}_{\mathrm{p}}$ and Homarus gammarus at both sites. Catches were slightly higher at the 2 platforms than at the respective control sites, and gradually increased at $R_{p}$ and $R_{c}$ from YA1 to YA3. Differences were not statistically significant either between sites or among years (Fig. 4, Table 4).

\section{Species diversity}

$H^{\prime}$ was ubiquitously rather high, being always greater than 0.6. It followed similar trends at $R_{p}$ and $R_{c}$, without significant variations among years, but with significantly higher values at the platform. In contrast, a gradual increase occurred at $A_{p}$ from $Y C$ to $Y A 2$, but not at $A_{c}$. No significant differences were found either between the 2 sites or among sampling years (Fig. 6, Table 2).

\section{DISCUSSION}

Sampling aimed at studying fish assemblages in the vicinity of gas and oil platforms requires the use of passive fishing gears, since active gears are difficult to tow

Table 5. Trisopterus minutus capelanus. Results of KolmogorovSmirnov test comparing catch demography between 2 gas platforms and between each platform and its respective control site. ${ }^{* *}$ Highly significant; abbreviations as in Table 1

\begin{tabular}{|cccc|}
\hline & $\mathrm{R}_{\mathrm{p}}$ & $\mathrm{A}_{\mathrm{p}}$ & $\mathrm{A}_{\mathrm{p}}$ \\
\hline $\mathrm{R}_{\mathrm{c}}$ & $0.008^{* *}$ & & \\
$\mathrm{~A}_{\mathrm{c}}$ & & 0.364 & \\
$\mathrm{R}_{\mathrm{p}}$ & & & $0.000^{* *}$ \\
\hline
\end{tabular}

near rigs (Soldal et al. 2002). In this context, the trammel net, besides being less selective than other passive gears (Fabi et al. 2002b, Løkkeborg et al. 2002), is also the most suitable technique for sampling in the vicinity of artificial structures on a regular basis (Bombace et al. 1997). In spite of this, the limited height of the net in relation to the water column and its selectivity may have undersampled the fish assemblages, and especially pelagic fishes, both around the platforms and at the open-sea control sites.

Higher species richness, diversity and catch rates were recorded at the platforms than at the control sites, indicating that, as reported for the Gulf of Mexico (Stanley \& Wilson 1990, 1997), California (Love \& Westphal 1990, Love et al. 1994, Helvey 2002) and the North Sea (Olsen \& Valdemarsen 1977, Løkkeborg et al. 2002), in the Adriatic Sea these structures act as artificial reefs, attracting aggregations of fish species and leading to enrichment and greater diversification of the local fish assemblage.

These effects were mainly due to the higher occurrence around the structures of reef-dwelling or partially reef-dwelling species, which are less common in the natural habitat. As for artificial reefs, orientation, higher prey availability and shelter may be some of the factors inducing fishes to congregate around offshore platforms. In addition, the platforms extend throughout the entire water column, with a unique facility to attract fishes in all water layers from the bottom to the surface (Grove et al. 1991). In our study, pelagic and nekto-benthic species dominated in catches around the platforms, where they probably gather mainly for orientation and because of higher prey densities. One of the most representative PA nekto-benthic species at both platforms was the poor cod Trisopterus minutus capelanus, which was more abundant than at the open-sea control sites, in accordance with the adults' habit of aggregating near submerged hard substrates (Froglia 1981, Spanò et al. 1998). Also, the greater occurrence of large specimens at $R_{p}$ than at $A_{p}$ is consistent with the inverse size/depth relationship observed for this species in the Tyrrhenian Sea (Biagi et al. 1996).

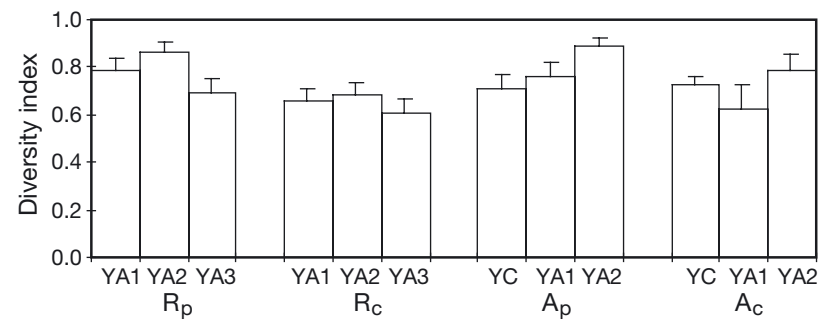

Fig. 6. Mean $(+\mathrm{SE})$ diversity index per year for catches at the 2 platforms and their respective control sites. Abbreviations as in Figs. $1 \& 2$ 
On the other hand, high prey and shelter availability may attract reef-dwelling benthic fishes such as scorpenids, which may find a suitable habitat in the large shell mounds formed by mussels Mytilus galloprovincialis falling from the rig on to the seabed and thus creating a specific ecosystem (Fabi et al. 2002a, in press). Most scorpenids caught at $\mathrm{R}_{\mathrm{p}}$ and $\mathrm{A}_{\mathrm{p}}$ were adults, as reported by Love et al. $(1994,1999,2000)$, who observed high abundances of subadult and adult rockfishes associated with large amounts of mussel shells on the seabed underneath offshore platforms in Santa Barbara Channel, California. Other voracious predators such as Lophius spp., which have no affinity to hard substrates, were recorded at $\mathrm{A}_{\mathrm{p}}$, probably attracted by the richness of prey.

As already observed in other areas (Stanley \& Wilson 1991, 1996, 1997, Løkkeborg et al. 2002), some differences were found in abundance, composition and evolution of the fish assemblages between the 2 platforms, probably as a function of differences in depth and distance from the coast.

Comparing the 2 rigs in YA1 and YA2 with their respective control sites, both platforms showed their influence in terms of species richness and diversity within the first year after the end of installation. In contrast, from a quantitative point of view, the platform furthest offshore and in deepest water displayed somewhat higher fish abundances than that closer to shore in shallower waters, reflecting a greater and faster aggregation effect. This difference was mainly due to an increase in mobile, pelagic and nekto-benthic species, which are partially attracted by hard substrates, and their faster colonisation of $A_{p}$ might be due to the shorter distance $(5.5 \mathrm{~km})$ of this platform from the next platform, in contrast to $\mathrm{R}_{\mathrm{p}}$, which is $\sim 12 \mathrm{~km}$ from the nearest platform. In addition, as pelagic fishes respond to visual attraction by the structure rather than to physical parameters such as submerged surface area and volume of water enclosed (Stanley \& Wilson 1991), their lower occurrence at $R_{p}$ might be a consequence of the greater water turbidity at this platform, which is more affected by river inflow than is $A_{p}$ (Revelante \& Gilmartin 1976, 1992, Krasakopoulou \& Souvermezoglou 1996).

On the other hand, a faster and greater colonisation by AT nekto-benthic species, especially seabreams (i.e. Diplodus sargus, D. vulgaris, Spondyliosoma cantharus) and corbs (Sciaena umbra and Umbrina cirrosa) occurred at $R_{p}$ than at $A_{p}$, probably because the water depth of the former platform lies more within the preferred ranges of these species in the central and northern Adriatic Sea. Moreover, most of them are less mobile than other PA species such as Pagellus bogaraveo and $P$. erythrinus, which rapidly increased at $A_{p}$.
From an ecological point of view, the occurrence of specific fish assemblages associated with the invertebrate populations encrusting the pilings (especially mussels; authors' unpubl. data) and settled on the large shell mounds that had fallen from the upper parts of the platforms to the sea bottom (Fabi et al. in press) indicates that in the Adriatic Sea the gas platforms increase the habitat complexity of the flat and homogeneous bottoms of the basin, providing additional habitat for reef-dwelling species. Because of their open structure and lack of interstitial spaces, platforms may be not as efficient as artificial reefs at attracting or increasing some fish species that are strictly dependent on such shelters. However, taking into account that each platform is surrounded by a $0.5 \mathrm{~km}$ radius protection zone in which all types of fishery, professional and recreational, is prohibited and that the seabed of the Adriatic Sea is strongly exploited by trawlers, the gas platforms can represent small protected areas where various fish species, at different stages of their life, may have greater survival opportunities. Therefore, the presence of a large number of these structures can contribute to increasing fish biomass, even though at present it is impossible to evaluate what the effect may be on the fish stocks of the region as a whole.

Acknowledgements. We would like to thank A. Lucchetti, A. Marziali and all the other people who actively participated in the sampling at sea and in the laboratory analysis. Thanks also to F. Luccarini for help with the statistical analysis.

\section{LITERATURE CITED}

Biagi F, De Ranieri S, Rocca V (1996) Relazione tagliaprofondità di specie ittiche nell'Arcipelago Toscano Meridionale. Biol Mar Medit 3:527-528

Bombace G, Fabi G, Fiorentini L, Speranza S (1994) Analysis of the efficacy of artificial reefs located in five different areas of the Adriatic Sea. Bull Mar Sci 55:559-580

Bombace G, Fabi G, Fiorentini L, Spagnolo A (1997) Assessment of the ichthyofauna of an artificial reef through visual census and trammel net: comparison between the two sampling techniques. In: Hawkins LE, Hutchinson $\mathrm{S}$ (eds) The responses of marine organisms to their environments. Southampton Oceanographic Centre, University of Southampton, UK, p 291-305

Bombace G, Fabi G, Rivas G (1999) Effetti sul popolamento ittico indotti da una piattaforma estrattiva dell'Alto Adriatico: prospettive di gestione delle risorse future. Biol Mar Medit 6:64-72

Fabi G, Grati F, Lucchetti A, Trovarelli L (2002a) Evolution of the fish assemblage around a gas platform in the northern Adriatic Sea. ICES J Mar Sci 59 (Suppl):309-315

Fabi G, Sbrana M, Biagi F, Grati F, Leonori I, Sartor P (2002b) Trammel and gill net selectivity for Lithognathus mormyrus (L., 1758), Diplodus annularis (L., 1758) and Mullus barbatus (L., 1758) in the Adriatic and the Ligurian seas. Fish Res 54:375-388 
Fabi G, Ausili S, Campanelli A, De Biasi A and 9 others (in press) Methods of assessing the ecological impact of gas platforms in the Adriatic Sea: two different scenarios. In: Libro de ponencias del II Congreso Internacional de Ciencia y Tecnologia Marina, Artes Graficas Vda. De Luis Castrillo, Madrid

Froglia C (1981) Summary of biological parameters of Trisopterus minutus capelanus (Risso) in the Adriatic. FAO Fish Rep 253:97-100

Furevik DM, Valdemarsen JW (1995) The importance of the Odin oil-field as a fishing area. Fisken Havet 6

Gallaway BJ, Martin LR, Howard RL, Boland GS, Dennis GD (1981) Effects on artificial reef and demersal fish and macrocrustacean communities. Mar Sci 14:237-299

Gerlotto F, Bercy C, Bordeay B (1989) Echo-integration survey around offshore oil-extraction platforms off Cameroon. Proc Inst Acoust 11:79-88

Grove RS, Sonu CJ, Nakamura M (1991) Design and engineering of manufactured habitats for fisheries enhancement. In: Seaman W Jr, Sprague LM (eds) Artificial habitats for marine and freshwater fisheries. Academic Press, San Diego, p 109-152

Hastings RW, Ogren LH, Mabry MT (1976) Observations on the fish fauna associated with offshore platforms in the north-eastern Gulf of Mexico. Fish Bull US Nat Mar Fish Serv 74:387-401

Helvey M (2002) Are southern California oil and gas platforms essential fish habitat? ICES J Mar Sci 59:S266-S271

Jørgensen T, Løkkeborg S, Soldal AV (2002) Residence of fish in the vicinity of a decommissioned oil platform in the North Sea. ICES J Mar Sci 59: S288-S293

Krasakopoulou E, Souvermezoglou E (1996) Variability of total suspended matter, particulate carbon and nitrogen in the surface and bottom layers of the northern Adriatic Sea. In: Hopkins TS, Artegiani A, Cauwet G, Degobbis D, Malej A (eds) The Adriatic Sea. Ecosystems research report 32, European Commission, Office for Official Publications of the European Communities, Brussels, p 225-229

Lindman HR (1992) Analysis of variance in experimental design. Spinger-Verlag, New York

Løkkeborg S, Humborstad OB, Jørgensen T, Soldal AV (2002) Spatio-temporal variations in gillnet catch rates in the vicinity of North Sea oil platforms. ICES J Mar Sci 59 (Suppl):294-299

Love MS, Westphal W (1990) Comparison of fishes taken by a sport fishing party vessel around oil platforms and adjacent natural reefs near Santa Barbara, California. Fish Bull US Nat Mar Fish Serv 88:599-605

Love MS, Hyland J, Ebeling A, Herrlinger T, Brooks A, Imamura E (1994) A pilot study of the distribution and abundances of rock fishes in relation to natural environmental factors at an offshore oil and gas production platform off the coast of southern California. Bull Mar Sci 55: 1062-1085

Love MS, Caselle JE, Snook L (1999) Fish assemblages on mussel mounds surrounding seven oil platforms in the Santa Barbara Channel and Santa Marina Basin. Bull Mar Sci 65:497-513
Love MS, Caselle JE, Snook L (2000) Fish assemblages around seven oil platforms in the Santa Barbara Channel area. Fish Bull US Nat Mar Fish Serv 98:96-117

Olsen S, Valdemarsen JW (1977) Fish distribution studies around offshore installations. Int Counc Explor Sea CM 1977/B:41

Page HM, Dugan JE, Dugan DS, Richards JB, Hubbard DM (1999) Effects of an offshore oil platform on the distribution and abundance of commercially important crab species. Mar Ecol Prog Ser 185:47-57

Pielou EC (1974) Population and community ecology: principles and methods. Gordon \& Breach, New York

Putt RE Jr (1982) A quantitative study of fish population associated with a platform within Buccaneer oil field, northwestern Gulf of Mexico. MS thesis, Texas A\&M University, College Station, TX

Revelante N, Gilmartin M (1976) The effects of Po River discharge on phytoplankton dynamics in the Northern Adriatic Sea. Mar Biol 34:259-271

Revelante N, Gilmartin M (1992) The lateral advection of particulate organic matter from the Po Delta region during summer stratification, and its implications for the Northern Adriatic. Estuar Coast Shelf Sci 35:191-212

Scarborough-Bull A, Kendall JJ Jr (1994) An indication of the process: offshore platforms as artificial reefs in the Gulf of Mexico. Bull Mar Sci 55:1086-1098

Siegel S (1956) Nonparametric statistics for behavioural sciences. McGraw-Hill, New York

Soldal AV, Svelldingen I, Jørgensen T, Løkkeborg S (2002) Rigs-to-reefs in the North Sea: hydroacoustic quantification of fish associated with a 'semi-cold' platform. ICES J Mar Sci 59:S281-S287

Spanò N, Rinelli P, Greco S (1998) Osservazioni su di una cattura eccezionale di Trisopterus minutus capelanus (Lacepede, 1800) nel Golfo di Patti (Sicilia nord-orientale). Biol Mar Medit 5:97-99

Stanley DR, Wilson CA (1990) A fishery-dependent based study of fish species composition and associated catch rates around oil and gas platform structures off Lousiana. Fish Bull US Nat Mar Fish Serv 88:719-730

Stanley DR, Wilson CA (1991) Factors affecting the abundance of selected fishes near oil and gas platforms in the northern Gulf of Mexico. Fish Bull US Nat Mar Fish Serv 89:149-159

Stanley DR, Wilson CA (1996) The use of hydroacoustics to determine abundance and size distribution of fishes associated with a petroleum platform. ICES J Mar Sci 53: 473-475

Stanley DR, Wilson CA (1997) Seasonal and spatial variation in abundance and size distribution of fishes associated with a petroleum platform in the northern Gulf of Mexico. Can J Fish Aquat Sci 54:1166-1176

Stanley DR, Wilson CA (1998) Spatial variation in fish density at three petroleum platforms as measured with dual-beam hydroacustics. Gulf Mex Sci 16:73-82

Valdemarsen JW (1979) Behavioural aspects of fish in relation to oil platforms in the North Sea. Int Counc Explor Sea CM 1979/B:27 
Appendix 1. Species caught at the Regina platform $\left(\mathrm{R}_{\mathrm{p}}\right)$ and at the control site $\left(\mathrm{R}_{\mathrm{c}}\right)$ with mean abundance $\left(\mathrm{N}_{;}\right.$ind. per $500 \mathrm{~m}$ per $\left.12 \mathrm{~h}\right)$ and biomass (W; kg per $500 \mathrm{~m}$ per $12 \mathrm{~h}$ ). Hab. = habitat; Attr. = attraction; $\mathrm{P}=$ pelagic $; \mathrm{NB}=$ nekto-benthic $\mathrm{B}=\mathrm{benthic} \mathrm{AT}=\mathrm{attracted} ;$ $\mathrm{PA}=$ partially-attracted; NA = non-attracted; YA1: 1st year after construction; YA2: 2nd year after construction; YA3: 3rd year after construction; No. of hauls $=12$, except YA3: 11

\begin{tabular}{|c|c|c|c|c|c|c|c|c|c|c|c|c|c|c|}
\hline \multirow{3}{*}{ Species } & \multicolumn{2}{|c|}{ Category } & \multicolumn{6}{|c|}{$-\mathrm{R}_{\mathrm{n}}$} & \multicolumn{4}{|c|}{$\mathrm{R}_{c}$} & \multirow{2}{*}{\multicolumn{2}{|c|}{ YA3 }} \\
\hline & \multirow{2}{*}{ Hab. } & Attr. & & & & A 2 & & A3 & & A1 & & Á 2 & & \\
\hline & & & $\mathrm{N}$ & W & $\mathrm{N}$ & W & $\mathrm{N}$ & W & $\mathrm{N}$ & W & $\mathrm{N}$ & W & $\mathrm{N}$ & W \\
\hline Fishes & & & & & & & & & & & & & & \\
\hline Seriola dumerili & $\mathrm{P}$ & AT & 0.5 & 0.16 & & & 0.4 & 0.17 & & & & & 0.1 & 0.02 \\
\hline Alosa fallax & $\mathrm{P}$ & NA & 1.6 & 0.47 & 1.0 & 0.29 & 2.3 & 0.64 & 2.0 & 0.54 & 3.2 & 0.78 & 4.7 & 1.59 \\
\hline Engraulis encrasicolus & $\mathrm{P}$ & NA & 13.2 & 0.17 & 10.7 & 0.11 & 18.2 & 0.16 & 20.2 & 0.26 & 11.9 & 0.12 & 21.5 & 0.21 \\
\hline Galeorhinus galeo & $\mathrm{P}$ & NA & & & & & & & 0.3 & 0.08 & & & & \\
\hline Prionace glauca & $\mathrm{P}$ & NA & & & & & & & & & 0.1 & 0.15 & & \\
\hline Sardina pilchardus & $\mathrm{P}$ & NA & 7.8 & 0.26 & 16.3 & 0.59 & 2.6 & 0.09 & 43.8 & 1.48 & 17.5 & 0.55 & 2.5 & 0.09 \\
\hline Sardinella aurita & $\mathrm{P}$ & NA & 1.4 & 0.20 & & & & & 2.2 & 0.39 & 0.1 & 0.02 & & \\
\hline Boops boops & $\mathrm{P}$ & PA & 18.5 & 1.38 & 11.4 & 0.91 & 18.5 & 1.67 & 19.0 & 1.40 & 4.7 & 0.42 & 1.7 & 0.13 \\
\hline Lichia amia & $\mathrm{P}$ & PA & 0.1 & 0.02 & & & & & & & & & & \\
\hline Liza ramada & $\mathrm{P}$ & PA & & & 0.3 & 0.15 & 0.2 & 0.12 & & & & & & \\
\hline Liza saliens & $\mathrm{P}$ & $\mathrm{PA}$ & 0.1 & 0.04 & & & & & & & & & 0.1 & 0.01 \\
\hline Sarda sarda & $\mathrm{P}$ & PA & 0.1 & 0.05 & & & & & 0.1 & 0.08 & & & 0.1 & 0.02 \\
\hline Scomber japonicus & $\mathrm{P}$ & $\mathrm{PA}$ & 1.0 & 0.18 & 0.1 & $-^{\mathrm{a}}$ & 0.1 & 0.02 & 0.2 & 0.02 & & & 0.6 & 0.10 \\
\hline Scomber scombrus & $\mathrm{P}$ & $\mathrm{PA}$ & 1.8 & 0.24 & 1.6 & 0.30 & 2.8 & 0.41 & 4.7 & 0.53 & 4.0 & 0.57 & 7.5 & 0.73 \\
\hline Spicara flexuosa & $\mathrm{P}$ & PA & 0.3 & 0.02 & 1.6 & 0.09 & 2.4 & 0.14 & 1.2 & 0.06 & 0.6 & 0.30 & 0.5 & 0.03 \\
\hline Trachurus mediterraneus & $\mathrm{P}$ & PA & 2.0 & 0.38 & 1.4 & 0.31 & 4.9 & 0.74 & 1.1 & 0.17 & 1.0 & 0.23 & 7.5 & 1.17 \\
\hline Trachurus trachurus & $\mathrm{P}$ & PA & 1.3 & 0.09 & 1.3 & 0.07 & 0.3 & 0.02 & 0.3 & 0.01 & 0.2 & 0.01 & & \\
\hline Dicentrarchus labrax & NB & AT & 0.1 & 0.02 & & & & & & & & & & \\
\hline Diplodus sargus & NB & AT & 0.2 & 0.02 & 0.6 & 0.07 & 0.3 & 0.03 & & & 0.1 & 0.01 & & \\
\hline Diplodus vulgaris & NB & AT & 0.1 & $-^{\mathrm{a}}$ & 1.0 & 0.10 & 0.1 & 0.01 & & & & & 0.1 & 0.01 \\
\hline Labrus merula & NB & AT & & & 0.1 & 0.02 & & & & & & & & \\
\hline Oblada melanura & NB & AT & & & 0.3 & 0.06 & 0.3 & 0.05 & & & 0.1 & 0.02 & 0.1 & 0.03 \\
\hline Sciaena umbra & NB & AT & 0.2 & 0.04 & 2.1 & 0.53 & 0.2 & 0.02 & & & 0.1 & 0.02 & & \\
\hline Sparus auratus & NB & AT & 0.1 & 0.04 & 0.1 & 0.01 & & & 0.1 & 0.01 & 0.3 & 0.04 & & \\
\hline Spondyliosoma cantharus & NB & AT & 0.1 & 0.01 & 0.3 & 0.05 & 0.1 & 0.01 & & & & & & \\
\hline Umbrina cirrosa & NB & AT & 3.1 & 0.59 & 2.6 & 0.46 & 10.0 & 2.04 & & & 0.1 & 0.02 & 0.1 & 0.01 \\
\hline Hipросатрus hippocampus & NB & NA & & & 0.1 & $-^{\mathrm{a}}$ & & & 0.1 & $-^{\mathrm{a}}$ & & & & \\
\hline Merlangius merlangus & NB & NA & 0.4 & 0.03 & 2.0 & 0.14 & 4.0 & 0.24 & 1.1 & 0.08 & 1.3 & 0.10 & 7.3 & 0.41 \\
\hline Merluccius merluccius & NB & NA & 0.3 & 0.02 & 0.3 & 0.08 & 0.3 & 0.02 & 0.9 & 0.28 & 0.2 & 0.03 & 0.4 & 0.06 \\
\hline Myliobatis aquila & NB & NA & & & & & & & 0.1 & 0.03 & 0.1 & 0.19 & & \\
\hline Diplodus annularis & NB & PA & 3.9 & 0.22 & 3.7 & 0.21 & 2.8 & 0.22 & & & 0.3 & 0.02 & 0.3 & 0.02 \\
\hline Lithognathus mormyrus & NB & PA & 0.1 & 0.01 & 0.9 & 0.16 & & & & & & & & \\
\hline Pagellus bogaraveo & NB & PA & 6.0 & 0.27 & 1.0 & 0.03 & 1.9 & 0.09 & 0.2 & 0.01 & 0.1 & $-^{a}$ & & \\
\hline Pagellus erythrinus & NB & $\mathrm{PA}$ & 0.5 & 0.01 & & & 0.3 & 0.02 & 0.3 & 0.01 & 0.3 & 0.01 & 0.1 & 0.01 \\
\hline Serranus hepatus & NB & PA & & & & & 0.1 & $-^{a}$ & & & 0.1 & $-{ }^{\mathrm{a}}$ & & \\
\hline Trisopterus minutus capelanus & NB & PA & 21.7 & 1.98 & 10.0 & 1.03 & 3.6 & 0.23 & 0.2 & 0.02 & 1.1 & 0.05 & 0.2 & 0.03 \\
\hline Conger conger & B & AT & & & & & 0.2 & 0.28 & & & & & & \\
\hline Gaidropsarus mediterraneus & B & AT & & & 0.1 & 0.02 & & & & & & & & \\
\hline Mullus surmuletus & B & AT & 0.1 & 0.01 & & & & & & & 0.1 & $-^{\mathrm{a}}$ & & \\
\hline Scorpaena notata & B & AT & 0.1 & $-^{\mathrm{a}}$ & 0.7 & 0.04 & 0.1 & 0.01 & & & & & & \\
\hline Scorpaena porcus & B & AT & 2.5 & 0.36 & 7.3 & 1.15 & 5.6 & 0.64 & 0.1 & 0.01 & 0.1 & 0.01 & & \\
\hline Scorpaena scrofa & B & AT & 0.1 & 0.01 & & & & & & & & & & \\
\hline Arnoglossus laterna & B & NA & 0.1 & $-^{\mathrm{a}}$ & 0.3 & 0.01 & 0.2 & $--^{\mathrm{a}}$ & & & 0.1 & $-{ }^{a}$ & 0.2 & $-^{a}$ \\
\hline Buglossidium luteum & B & NA & & & & & 0.1 & $--^{a}$ & & & & & & \\
\hline Dasyatis violacea & B & NA & & & & & & & & & 0.1 & 0.72 & 0.1 & 0.67 \\
\hline Eutrigla gurnardus & B & NA & & & & & & & & & & & 0.2 & $-^{a}$ \\
\hline Mullus barbatus & B & NA & 1.4 & 0.06 & 2.4 & 0.10 & 2.5 & 0.11 & 2.6 & 0.10 & 4.7 & 0.21 & 2.5 & 0.14 \\
\hline Psetta maxima & B & NA & & & & & & & & & & & 0.1 & 0.02 \\
\hline Raja asterias & B & NA & & & & & & & & & 0.1 & 0.07 & & \\
\hline Scophthalmus rhombus & B & NA & & & & & 0.2 & 0.03 & 0.1 & 0.04 & 0.1 & 0.01 & 0.1 & 0.01 \\
\hline Solea vulgaris & $\mathrm{B}$ & NA & 3.2 & 0.36 & 4.3 & 0.56 & 5.5 & 0.71 & 4.2 & 0.48 & 9.3 & 1.09 & 8.6 & 1.06 \\
\hline Torpedo marmorata & B & NA & & & & & & & & & & & 0.1 & 0.07 \\
\hline Trigla lucerna & B & NA & 2.1 & 0.23 & 10.5 & 0.47 & 2.6 & 0.27 & 9.0 & 0.77 & 27.9 & 1.23 & 5.8 & 0.59 \\
\hline Uranoscopus scaber & $\mathrm{B}$ & NA & & & & & 0.1 & $-{ }^{a}$ & & & & & & \\
\hline Gobius niger & $\mathrm{B}$ & PA & 0.6 & 0.02 & 0.2 & $-^{\mathrm{a}}$ & 0.4 & 0.01 & 0.7 & 0.02 & 0.6 & 0.01 & 0.8 & 0.02 \\
\hline Molluscs & & & & & & & & & & & & & & \\
\hline Loligo vulgaris & $\mathrm{P}$ & PA & 0.1 & 0.03 & 0.1 & 0.01 & & & & & & & & \\
\hline Bolinus brandaris & $\mathrm{B}$ & AT & 0.4 & 0.01 & 1.3 & 0.05 & 7.9 & 0.30 & 1.3 & 0.04 & 1.2 & 0.03 & 0.2 & $-^{\mathrm{a}}$ \\
\hline Sepia officinalis & B & NA & & & 0.2 & 0.09 & 0.5 & 0.19 & & & & & & \\
\hline Eledone cirrhosa & B & PA & 0.1 & 0.03 & & & & & & & & & & \\
\hline Eledone moschata & B & PA & & & & & & & & & 0.1 & 0.05 & & \\
\hline Crustaceans & & & & & & & & & & & & & & \\
\hline Homarus gammarus & B & AT & & & & & 0.1 & 0.06 & & & & & & \\
\hline Maja crispata & B & AT & 0.1 & 0.01 & 0.4 & 0.02 & 0.2 & 0.01 & & & & & & \\
\hline Penaeus kerathurus & B & NA & 0.1 & $-^{\mathrm{a}}$ & 0.1 & $-^{\mathrm{a}}$ & 0.8 & 0.03 & 0.5 & 0.02 & 0.1 & $-^{\mathrm{a}}$ & 0.2 & 0.01 \\
\hline Squilla mantis & $\mathrm{B}$ & NA & 30.7 & 1.46 & 34.4 & 1.72 & 64.9 & 3.36 & 34.6 & 1.60 & 43.2 & 1.96 & 56.0 & 2.91 \\
\hline Total & & & 128.2 & 9.51 & 133.1 & 10.0 & 168.6 & 13.2 & 151.2 & 8.5 & 135.2 & 9.1 & 130.3 & 10.2 \\
\hline${ }^{\mathrm{a}}<0.01$ & & & & & & & & & & & & & & \\
\hline
\end{tabular}


Appendix 2. Species caught at the Annalisa platform $\left(A_{p}\right)$ and at the control site $\left(A_{c}\right)$ with mean abundance $\left(N_{i}\right.$ ind. per $500 \mathrm{~m}$ per $\left.12 \mathrm{~h}\right)$ and biomass (W; kg per $500 \mathrm{~m}$ per $12 \mathrm{~h}$ ). No. of hauls = YC: 9, YA1: 10, YA2: 11. Abbreviations as in Appendix 1

\begin{tabular}{|c|c|c|c|c|c|c|c|c|c|c|c|c|c|c|}
\hline \multirow[t]{3}{*}{ Species } & \multicolumn{2}{|c|}{ Category } & \multicolumn{4}{|c|}{$-\mathrm{A}_{\mathrm{p}}-$} & \multirow{2}{*}{\multicolumn{2}{|c|}{ YA2 }} & 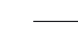 & & $-A$ & & & \\
\hline & Hab. & Attr. & & & & A 1 & & & $\mathrm{Y}$ & $\mathrm{C}$ & & & & A2 \\
\hline & & & $\mathrm{N}$ & W & $\mathrm{N}$ & W & $\mathrm{N}$ & W & $\mathrm{N}$ & W & $\mathrm{N}$ & W & $\mathrm{N}$ & W \\
\hline Fishes & & & & & & & & & & & & & & \\
\hline Seriola dumerili & $\mathrm{P}$ & AT & & & 0.1 & 0.03 & 0.4 & 0.46 & & & & & & \\
\hline Alosa fallax & $\mathrm{P}$ & NA & 0.5 & 0.22 & 0.1 & 0.04 & & & 0.4 & 0.11 & 0.7 & 0.36 & 0.3 & 0.14 \\
\hline Auxis rochei & $\mathrm{P}$ & NA & & & & & & & 0.1 & 0.03 & & & & \\
\hline Engraulis encrasicolus & $\mathrm{P}$ & NA & 4.3 & 0.07 & 16.1 & 0.25 & 17.6 & 0.25 & 2.0 & 0.03 & 28.5 & 0.38 & 0.5 & 0.01 \\
\hline Sardina pilchardus & $\mathrm{P}$ & NA & 1.0 & 0.04 & 5.1 & 0.20 & 1.5 & 0.05 & 0.7 & 0.03 & 4.7 & 0.17 & & \\
\hline Sardinella aurita & $\mathrm{P}$ & NA & & & & & 10.7 & 1.58 & & & & & 0.4 & 0.06 \\
\hline Boops boops & $\mathrm{P}$ & PA & 0.4 & 0.04 & 47.2 & 4.76 & 127.8 & 10.26 & 0.6 & 0.07 & 0.6 & 0.05 & 1.1 & 0.14 \\
\hline Liza ramada & $\mathrm{P}$ & PA & & & 0.1 & 0.05 & 0.1 & 0.03 & & & & & 0.1 & 0.05 \\
\hline Pomatomus saltator & $\mathrm{P}$ & $\mathrm{PA}$ & & & & & 5.8 & 2.08 & & & & & 0.2 & 0.07 \\
\hline Sarda sarda & $\mathrm{P}$ & PA & & & 1.1 & 0.98 & 7.8 & 6.34 & & & & & & \\
\hline Scomber japonicus & $\mathrm{P}$ & PA & 5.4 & 1.99 & 1.1 & 0.36 & 17.5 & 4.98 & 0.2 & 0.09 & 0.4 & 0.14 & 0.8 & 0.27 \\
\hline Scomber scombrus & $\mathrm{P}$ & PA & 0.4 & 0.08 & 4.8 & 0.53 & 3.5 & 0.60 & 1.0 & 0.20 & 1.4 & 0.15 & 0.7 & 0.14 \\
\hline Spicara flexuosa & $\mathrm{P}$ & PA & 0.4 & 0.02 & 21.4 & 1.23 & 36.7 & 2.22 & 0.6 & 0.04 & 0.5 & 0.03 & 0.5 & 0.02 \\
\hline Spicara maena & $\mathrm{P}$ & PA & & & & & 0.1 & 0.01 & & & & & & \\
\hline Spicara smaris & $\mathrm{P}$ & PA & & & & & & & & & & & 0.1 & $-^{a}$ \\
\hline Trachurus mediterraneus & $\mathrm{P}$ & $\mathrm{PA}$ & 0.9 & 0.20 & 5.4 & 0.82 & 58.7 & 9.30 & 0.9 & 0.18 & & & 0.3 & 0.03 \\
\hline Trachurus trachurus & $\mathrm{P}$ & PA & 2.2 & 0.20 & 13.9 & 1.14 & 20.5 & 2.40 & 0.1 & 0.01 & 0.1 & 0.01 & 0.9 & 0.09 \\
\hline Dentex dentex & NB & AT & & & & & 0.1 & 0.02 & & & & & & \\
\hline Diplodus vulgaris & NB & AT & 0.1 & 0.01 & & & 0.3 & 0.04 & 0.1 & 0.01 & & & & \\
\hline Sciaena umbra & NB & AT & & & 0.1 & 0.02 & & & & & & & & \\
\hline Sparus auratus & NB & AT & & & 0.1 & 0.02 & 0.9 & 0.13 & & & & & & \\
\hline Spondyliosoma cantharus & NB & AT & & & & & 0.4 & 0.08 & & & & & $-^{\mathrm{a}}$ & $-^{\mathrm{a}}$ \\
\hline Merlangius merlangus & NB & NA & 1.1 & 0.04 & 0.2 & 0.01 & 0.2 & 0.02 & 1.8 & 0.11 & 0.6 & 0.03 & & \\
\hline Merluccius merluccius & NB & NA & 2.1 & 0.38 & 0.2 & 0.02 & 0.9 & 0.10 & 4.4 & 0.89 & 0.4 & 0.08 & 0.4 & 0.13 \\
\hline Mustelus mustelus & NB & NA & & & & & 0.1 & 0.15 & & & & & $-^{\mathrm{a}}$ & 0.02 \\
\hline Myliobatis aquila & NB & NA & & & 0.7 & 3.72 & & & & & 0.2 & 0.61 & & \\
\hline Pagellus acarne & NB & NA & & & 0.2 & 0.02 & 1.1 & 0.05 & & & & & 0.3 & 0.02 \\
\hline Diplodus annularis & NB & $\mathrm{PA}$ & & & & & 0.1 & $-{ }^{a}$ & & & 0.1 & 0.01 & & \\
\hline Pagellus bogaraveo & NB & PA & & & 1.2 & 0.06 & 6.6 & 0.47 & & & & & 0.1 & $-^{\mathrm{a}}$ \\
\hline Pagellus erythrinus & NB & PA & & & 0.1 & $-{ }^{\mathrm{a}}$ & 5.2 & 0.37 & & & & & 0.2 & 0.02 \\
\hline Serranus hepatus & NB & PA & & & & & 0.1 & $-^{\mathrm{a}}$ & & & 0.1 & $-^{\mathrm{a}}$ & & \\
\hline Trisopterus minutus capelanus & NB & PA & 13.0 & 0.76 & 18.1 & 1.13 & 34.8 & 1.83 & 7.2 & 0.37 & 4.0 & 0.22 & 3.1 & 0.12 \\
\hline Zeus faber & NB & PA & & & & & 0.2 & 0.05 & & & & & 0.1 & 0.03 \\
\hline Mullus surmuletus & $\mathrm{B}$ & AT & & & 0.2 & 0.01 & 1.0 & 0.12 & & & & & 0.1 & 0.02 \\
\hline Scorpaena notata & $\mathrm{B}$ & AT & 0.6 & 0.03 & 1.0 & 0.06 & 3.2 & 0.20 & & & & & 0.2 & 0.01 \\
\hline Scorpaena porcus & $\mathrm{B}$ & AT & & & 0.5 & 0.07 & 1.6 & 0.25 & & & & & $-{ }^{\mathrm{a}}$ & 0.01 \\
\hline Buglossidium luteum & $\mathrm{B}$ & NA & 0.1 & $-^{a}$ & & & & & & & & & & \\
\hline Cepola macrophthalma & B & NA & & & & & & & 0.1 & 0.01 & & & & \\
\hline Dasyatis violacea & B & NA & & & & & & & & & & & 0.1 & 0.33 \\
\hline Eutrigla gurnardus & B & NA & & & 0.7 & 0.01 & 0.1 & 0.01 & & & 0.2 & 0.01 & & \\
\hline Lepidotrigla cavillone & B & NA & & & 0.1 & $-{ }^{a}$ & 0.2 & $-{ }^{a}$ & & & 0.1 & $-{ }^{\mathrm{a}}$ & & \\
\hline Lophius budegassa & $\mathrm{B}$ & NA & & & 0.1 & & 0.2 & 0.10 & & & & & 0.1 & 0.05 \\
\hline Lophius piscatorius & $\mathrm{B}$ & NA & 0.1 & 0.02 & 0.2 & 0.18 & & & & & & & & \\
\hline Microchirus variegatus & B & NA & & & 0.9 & 0.02 & 3.0 & 0.07 & 0.3 & 0.01 & 0.5 & 0.01 & 0.4 & 0.01 \\
\hline Mullus barbatus & B & NA & 0.2 & 0.01 & 0.4 & 0.02 & 1.8 & 0.10 & 0.2 & 0.01 & 0.3 & 0.02 & 0.1 & $-^{\mathrm{a}}$ \\
\hline Mustelus asterias & B & NA & 0.1 & 0.09 & & & & & & & & & & \\
\hline Scophthalmus rhombus & B & NA & 0.2 & 0.18 & & & & & & & & & & \\
\hline Scyliorhinus canicula & B & NA & 0.2 & 0.06 & 0.1 & 0.03 & & & 0.2 & 0.07 & & & 0.1 & 0.03 \\
\hline Solea vulgaris & $\mathrm{B}$ & NA & 3.7 & 0.60 & 2.3 & 0.31 & 2.7 & 0.37 & 5.0 & 0.66 & 3.2 & 0.45 & 3.7 & 0.52 \\
\hline Squalus acanthias & $\mathrm{B}$ & NA & 1.1 & 0.71 & 0.6 & 0.29 & 1.0 & 0.52 & 1.8 & 1.57 & 1.0 & 0.68 & 2.0 & 1.29 \\
\hline Torpedo marmorata & B & NA & & & 1.1 & 0.52 & 0.1 & 0.05 & & & & & 0.1 & 0.07 \\
\hline Trachinus draco & B & NA & & & 0.1 & $-^{\mathrm{a}}$ & 0.2 & 0.01 & & & & & & \\
\hline Trigla lucerna & $\mathrm{B}$ & NA & 7.0 & 0.55 & 2.5 & 0.39 & 1.2 & 0.24 & 8.7 & 0.91 & 3.4 & 0.45 & 1.8 & 0.30 \\
\hline Uranoscopus scaber & B & NA & & & & & 0.1 & $--^{\mathrm{a}}$ & & & & & & \\
\hline Gobius niger & B & PA & & & & & 0.1 & $-{ }^{\mathrm{a}}$ & & & & & 0.1 & $-^{a}$ \\
\hline Molluscs & & & & & & & & & & & & & & \\
\hline Illex coindetii & & NA & & & 0.1 & $-{ }^{a}$ & 0.6 & 0.09 & & & & & & \\
\hline Loligo vulgaris & $\mathrm{P}$ & $\mathrm{PA}$ & 0.1 & 0.05 & & & 0.1 & 0.06 & & & 0.1 & 0.03 & & \\
\hline Bolinus brandaris & B & AT & & & & & & & 0.1 & $-^{\mathrm{a}}$ & & & & \\
\hline Octopus vulgaris & $\mathrm{B}$ & AT & & & 0.1 & 0.23 & 0.1 & 0.94 & & & & & 0.1 & 0.23 \\
\hline Sepia officinalis & B & NA & & & 0.1 & 0.02 & 1.8 & 1.03 & 0.1 & 0.03 & & & 0.3 & 0.07 \\
\hline Eledone cirrhosa & $\mathrm{B}$ & $\mathrm{PA}$ & 0.1 & 0.04 & & & & & & & & & 0.1 & 0.02 \\
\hline Eledone moschata & $\mathrm{B}$ & PA & & & & & & & & & 0.1 & 0.03 & & \\
\hline Crustaceans & & & & & & & & & & & & & & \\
\hline Homarus gammarus & $\mathrm{B}$ & AT & & & 0.1 & 0.10 & 0.1 & 0.05 & & & & & & \\
\hline Maja squinado & B & NA & & & & & 0.2 & 0.19 & 0.1 & 0.07 & 0.1 & 0.06 & 0.1 & 0.09 \\
\hline Nephrops norvegicus & $\mathrm{B}$ & NA & 0.3 & 0.02 & 0.2 & 0.02 & 0.1 & 0.01 & 0.3 & 0.03 & 0.2 & 0.02 & 0.2 & 0.01 \\
\hline Penaeus kerathurus & $\mathrm{B}$ & NA & & & & & 0.1 & 0.01 & & & & & & \\
\hline Squilla mantis & B & NA & & & 0.1 & $-^{\mathrm{a}}$ & & & & & 0.1 & $-^{\mathrm{a}}$ & & \\
\hline Total & & & 45.7 & 6.42 & 148.5 & 17.69 & 378.9 & 48.3 & 37.0 & 5.54 & 51.5 & 3.99 & 19.6 & 4.4 \\
\hline${ }^{\mathrm{a}}<0.01$ & & & & & & & & & & & & & & \\
\hline
\end{tabular}

Editorial responsibility: Otto Kinne (Editor), Oldendorf/Luhe, Germany
Submitted: March 12, 2003; Accepted: November 13, 2003

Proofs received from author(s): May 11, 2004 